\title{
Framework for Collaborative Governance of Sustainable Economic Development
}

\author{
Anwar Sadat ${ }^{1 *}$ \\ ${ }^{1}$ Department of Governance Science, University of Muhammadiyah Buton, Baubau, Indonesia \\ *Corresponding author. Email: anwarsadat685@gmail.com
}

\begin{abstract}
Collaborative Governance in sustainable economic development has close relationship with people participation and the government itself. The problem that occurs in this context is viewed from the concept of Collaborative Governance that is the lack of contextual system inspected from the changing conditions of the legislation, the drive of leadership elements that greatly affect to the economic development, and the dynamics of collaboration which are unfavorable to all parties that makes sectoral egos still occur. The concept of Collaborative Governance as an alternative basis is considered capable to realize acceleration and implementation as a model to increase economic development in Buton by continuing to prioritize conservation efforts and program sustainability through institutional strengthening by establishing RegionalOwned Enterprises, MSMEs and cooperatives organized by local communities. To achieve economic development success, all program planning, implementation and development evaluation must involve the community, because the need to develop their territory will utilize and assess the success or failure of sustainable economic development in the region. The method in this study used qualitative methods by combining primary and secondary data. In the Development of Economic Development in Buton Regency, there is still a very low level of community participation that still occurs the differences perception in strengthening sustainable economic development and regional development.

Keywords: collaborative governance, development, sustainable
\end{abstract}

\section{INTRODUCTION}

For people and an inclusive economy such as Indonesia, the balance between economic development, social justice and regional progress must be clearly defined. In this respect, Collaborative Governance can unify public and private stakeholders collectively to be involved as the decision maker. Collaborative Governance in various policy sectors, has a role in identifying critical variables that will influence the governance model that determine success or unsuccessful collaboration. These variables involved a history of conflict or previous collaboration, participation incentives for stakeholders, imbalances in power and resources, leadership, and institutional design and also identify a set of factors that are very important in the collaborative process. These factors include face-to-face dialogue, building trust, commitment and mutual understanding. Good collaboration will tend to develop when collaborative forums focus on deciding 'small wins' that deepen trust, commitment, and shared understanding [1]. Collaboration begins with the development plan discussed by the Central Government, Provincial.

Governments, Regency / City Governments, and Village Governments. The concept of Collaborative Governance as an alternative basis is considered capable of realizing the acceleration and implementation of economic development in the regions. Collaborative Governance is a process in which various stakeholders are involved [2]. tephan Balogh stated that Collaborative Governance has three dimensions, they are system context, drivers, and collaboration dynamics. These dimensions can be explored as follows:

a. The first dimension is depicted as the outer box which become the scope or system of the context. The first dimension covers 7 elements they are:

1) Resource Condition,

2) Policy and Legal Framework,

3) Level of Conflict/Trust,

4) Socio-economic, health, cultural, and diversity (Portrait Conditions),

5) Prior failure to Address Issues,

6) Political dynamics/power relations, and

7) Network connectedness.

b. The second dimension is part of the concept of Collaborative Governance which consists of the dynamics of collaboration and collaborative action. Current conditions at the beginning of collaboration can facilitate or prevent collaboration between stakeholders and related agencies. Many frameworks tend to mix the contexts and conditions of a system with specific collaboration drivers. Conversely, a framework that separates contextual variables from important drivers, will not succeed without encouragement to collaborate. This second dimension has 4 components, namely:

1) Leadership, refers to a leader who can take the initiative to start and help prepare resources.

2) Consequential incentives, pointing to the internal part (the problem of resources, interests, or opportunities), and external (crisis, threats, situational / institutional opportunities). 
3) Interdependence, a condition when individuals and organizations cannot achieve something with the efforts and capacities of one party.

4) Uncertainty, uncertainty is a major challenge in managing public problems.

c. The third dimension is the dynamics of collaboration consisting of three components, that is: Principled Engagement, Shared, Motivation, Capacity for Join action [3]. The government has launched a program to improve the regional economy based on agriculture and tourism as wellas empowering local enterprises, cooperatives and MSMEs in agriculture and tourism services and their supporting businesses. However, it must be realized that the community empowerment activities carried out by the government are still partial and not optimal. This can be proved from the absence of real effort from the government in encouraging the growth of BUMD, MSME and community agricultural cooperatives. In addition, economic development in Buton District is a challenge. Therefore, the existence of BUMD MSME and Cooperatives is interesting to study. First, because it adheres to the principle of sustainability [4]. Collaborative governance includes participatory management, interactive policy making, stakeholder governance, and collaborative management. The term collaborative management covers various aspects, from the planning process, policy making, implementation to evaluation. Collaborative is also a term that shows more on a consensus-oriented and its approach [5]. There are scales or measurements in implementing collaborative governance, ranging from the highest level to the lowest level as shown in the table 1.

Table 1. Collaboration Scale

\begin{tabular}{|c|c|}
\hline Level of Collaboration & Activity and the actors \\
\hline $\begin{array}{l}\text { Highest level: high } \\
\text { commitment to collaborate; } \\
\text { highest political / managerial } \\
\text { risk }\end{array}$ & $\begin{array}{l}\text { A network of interactions between } \\
\text { Transformative actors; substantive } \\
\text { involvement and empowerment; } \\
\text { achievement of consensus and } \\
\text { cooperation between stakeholders or } \\
\text { between actors; a strong coalition } \\
\text { exists between the government and } \\
\text { non-government institutions. }\end{array}$ \\
\hline $\begin{array}{l}\text { Middle-high level: } \\
\text { collaboration orientation; } \\
\text { high political and managerial } \\
\text { risk }\end{array}$ & $\begin{array}{l}\text { Strong involvement of stakeholders in } \\
\text { decision making or policy processes } \\
\text { and implementation; transfer decision } \\
\text { making capacity for clients; more } \\
\text { complex innovations in the policy } \\
\text { process }\end{array}$ \\
\hline $\begin{array}{l}\text { Intermediate Level: } \\
\text { commitment to collaboration; } \\
\text { moderate political and } \\
\text { managerial risks }\end{array}$ & $\begin{array}{l}\text { Commitment to formal collaboration } \\
\text { for consultations between institutions; } \\
\text { actors joined the government; formal } \\
\text { involvement and joint funding } \\
\text { initiatives }\end{array}$ \\
\hline $\begin{array}{l}\text { Middle-low level: operational } \\
\text { form of collaboration to get } \\
\text { the work done; political and } \\
\text { managerial risks are rather } \\
\text { low }\end{array}$ & $\begin{array}{l}\text { Form of co-production; technical } \\
\text { improvements in collaboration; Help } \\
\text { to comply with obligations; direct } \\
\text { consultation with clients; systematic } \\
\text { process, use of evaluation data; } \\
\text { reporting to the public }\end{array}$ \\
\hline $\begin{array}{l}\text { The lowest level: operational } \\
\text { adjustments to collaboration, } \\
\text { low levels of political and } \\
\text { managerial risk }\end{array}$ & $\begin{array}{l}\text { Adjustment of collaboration; use } \\
\text { consultative processes; client } \\
\text { discussion and feedback mechanism; } \\
\text { get information about the needs / } \\
\text { expectations of others. }\end{array}$ \\
\hline
\end{tabular}

\section{RESEARCH METHOD}

This research aimed to analyze collaborative governance towards sustainable economic development through BUMD, MSME, cooperatives and community empowerment, to produce sustainable economic development through collaboration with various stakeholders. This research is expected to provide input for various parties who will design development models for BUMD, MSME and similar cooperatives. The method employed a qualitative approach, while data collection techniques are collected through interviews and observations as well as tracking various sources and literature from government documents as well as news coverage in print and electronic mass media, journals and books related to collaborative governance and sustainable economic development. Primary and secondary data is processed and described in the form of narration in accordance with the data and discussion needs. Then the data analysis process is carried out based on research findings, theories and concepts of collaborative governance and sustainable economic development and then the data interpretation process is carried out [6].

\section{RESULTS AND DISCUSSION}

\subsection{System context}

Collaborative governance begins and develops in a multilayered context of political, legal, socio-economic, environmental, and other influences. The context of this external system creates opportunities and constraints as well as influences Collaborative Governance to be implemented. Not only to the overall form of system context of Collaborative Governance but the regime itself can also influence the system context through the impact of collaborative action. Economic development program of Buton Regency in collaboration with CSR, NGOs especially to provide special schemes for BUMD, MSME and Cooperatives guidance which not yet bankable and feasible to realize sustainable economic development programs. Researcher himself have recognized several key elements in the context of the system that might distinguish or influence the nature and prospects of Collaborative Governance, including the condition of resources that need improvement, or limitation; policy and legal frameworks, including administrative, regulatory or judiciary; previous failures to resolve problems through conventional channels and authority; political dynamics and power relations in society and at the level of government; the level of inside connectedness and all existing networks; historic level of conflict between recognized interests and the level of trust and impact on employment relations; and socioeconomic and cultural health and diversity.

\subsection{Drivers}

In the context of drivers as one of the dimensions of collaborative governance, the most influential element is 
Leadership. The Economic Development should include the use and the utilization of Village-Owned Enterprises, MSMEs and Cooperatives in Buton Regency in the increasing of sustainable development to provide special schemes in accordance with Regency / City spatial planning. Service factors are carried out to improve the welfare of the community, infrastructure development, economic improvement, and the development of appropriate technology. Community empowerment factors aimed to increase access to services and economic activities. All those elements should be contained in the draft of economic development which must be discussed with the Government, Provincial Government, Buton District Government. The development plan was determined by the Buton Regency in accordance with the Regional Medium-Term Development Plan. The Regional Medium-Term Development Plan is a translation of the vision and mission of regional heads that reflects political objectives in the next five years. It needs commitment and consistency of the regional government in carrying out economic development, because this agenda will impact on the implementation of spatial planning of regions. Therefore, the role of the Regional Head will greatly influence sustainable economic development. In addition, the Buton Regency government must be able to identify and to map out regional and existing regulatory potential which can be maximized. Because the current problem is that there are still minimal guidelines and technical guidelines for economic development.

\subsection{Collaborative Dynamics}

The collaboration actually will benefit to all parties especially in terms of resources, because it raises potential of sharing and utilizing limited resources owned, this is called 'the capacity for Join action' as one of the elements of 'collaborative dynamics'. When it is seen in the context of regulation there has been a dynamic in its implementation. This reflected on the dynamics of the previous regulation that did not explicitly and specifically regulate sustainable economic development, thus making the implementation of equalized, even though the two development contexts have different substances. Community participation has been being a key word in the development, it is also become one of the characteristics of good governance. Community involvement can take the form of: (1) education and training, (2) active participation in information gathering, (3) participation in providing alternative plans and proposals to the government. Empirical conditions that occur at this time, open up development opportunities in the region more open and participatory mutually beneficial. In the context of Collaborative Governance, this opportunity certainly is in line with the opening of the other parties in planning and implementation development. This can be seen from several aspects. First, economic development, which includes: the stages of planning and monitoring, and supervision of economic development which involve various competent parties; Second, economic development which includes: the understanding and scope of rural area development, as well as the role and participation of regional governments and communities; The three economic development systems, which include: the rights and obligations of the government in developing RGIS (Regional Government Information Systems) and its management. Fourth, cooperation between regions and cooperation with third parties. The dynamics that have developed so far are clearly influencing economic development, therefore through this dimension, the government is expected to be able to identify and map economic development by building a consensus that involves relevant elements in any collaboration system.

\section{CONCLUSION}

Economic development program policies that are centralized tend to be incompatible with local needs and turn off social contexts. The concept of Collaborative Governance that happened is lacking of a contextual system that can be seen from the changing conditions of the legislation, drivers as seen from the leadership element that greatly influences regional development planning, and the occurrence of dynamics collaboration. These conditions cannot give beneficial to all parties, so that sectoral egos still occur, caused suboptimal development. Potential in advancing development by forming BUMD, MSME and Cooperatives for sustainable economic development and collaborating resources, can be started from the collaboration of the development plans from the level of the Central Government, Provincial Governments, Regency / Municipal Governments, and Village Governments, by involving various stakeholders related to the interests and potential of each agency in achieving common goals. So that the achievements of economic development in accelerating and improving the quality of services, development, and community empowerment through a participatory development approach with the integration of development between Regions in 1 (one) Regency / City can be realized properly.

\section{REFERENCES}

[1] C. Ansell and A. Gash, "Collaborative governance in theory and practice," J. Public Adm. Res. Theory, vol. 18, no. 4, pp. 543-571, 2008.

[2] R. A. Febrian, “Collaborative Governance Dalam Pembangunan Kawasan Perdesaan (Tinjauan Konsep dan Regulasi)," Pemerintahan, Polit. dan Birokrasi, vol. II, pp. 200-208, 2016.

[3] K. Emerson, T. Nabatchi, and S. Balogh, "An integrative framework for collaborative governance," J. Public Adm. Res. Theory, vol. 22, no. 1, pp. 1-29, 2012.

[4] H. Nasir et al., "Penguatan Pembangunan Ekonomi Berkelanjutan melalui UMKM dan Koperasi dalam Masyarakat Pedesaan (Studi Kasus : Petani Madu Hutan di Taman Nasional Ujung Kulon ) Pendahuluan Salah satu masalah yang hingga saat ini masih dihadapi 
goals with the next generation," Tour. Manag. Perspect., vol. 30, pp. 33-42, 2019.

[6] J. Danandjaja, "Metode Penelitian Kepustakaan," Antropol. Indones., 2014. programs: Meeting the 2030 sustainable development
[5] S. L. Slocum, D. Y. Dimitrov, and K. Webb, "The
impact of neoliberalism on higher education tourism

oleh Indonesia adalah kemi," J. Sospol, vol. 3, no. 2, pp. 122-138, 2017. 